\title{
Cytotoxicity and genotoxicity of Agaricus blazei methanolic extract fractions assessed using gene and chromosomal mutation assays
}

\author{
Marilanda Ferreira Bellini ${ }^{1}$, Leonardo Neves Cabrioti ${ }^{1}$, Ana Paula Terezan ${ }^{2}$, Berenice Quinzani Jordão ${ }^{1}$, \\ Lúcia Regina Ribeiro ${ }^{3}$ and Mário Sérgio Mantovani ${ }^{1}$ \\ ${ }^{1}$ Departamento de Biologia Geral, Universidade Estadual de Londrina, Londrina, PR, Brazil. \\ ${ }^{2}$ Departamento de Química, Universidade Federal de São Carlos, São Carlos, SP, Brazil. \\ ${ }^{3}$ Programa de Pós-graduação em Biologia Celular, Universidade Estadual Paulista, Rio Claro, SP, Brazil.
}

\begin{abstract}
Functional food investigations have demonstrated the presence of substances that could be beneficial to human health when consumed. However, the toxic effects of some substances contained in foods have been determined. Reported medicinal and nutritive properties have led to the extensive commercialization of the basidiomycete fungi Agaricus blazei Murrill (sensu Heinemann), also known as Agaricus brasiliensis Wasser et al., Agaricus subrufescens Peck or the Brazilian medical mushroom (BMM). Different methanolic extract fractions (ME) of this mushroom were submitted to the cytokinesis-block micronucleus (CBMN) clastogenic assay and the hypoxanthine-guanine phosphoribosyl transferase locus (HGPRT) assay for gene mutation, both using Chinese hamster ovary cells clone $\mathrm{K} 1$ ( $\mathrm{CHO}-\mathrm{K} 1)$. The results suggest that all the fractions tested possess cytotoxic and mutagenic potential but no clastogenic effects. Further information is needed on the biochemical components of the $A$. blazei methanol fractions to identify any substances with cytotoxic and/or mutagenicity potential. These findings indicate that $A$. blazei methanolic extract should not be used due to their genotoxicity and care should be taken in the use of $A$. blazei by the general population until further biochemical characterization of this fungi is completed.
\end{abstract}

Key words: Agaricus blazei, hgprt locus, micronucleus.

Received: January 29, 2007; Accepted: May 16, 2007.

\section{Introduction}

The increasing contact of people with novel synthetic and natural chemicals from plants and fungi means that there is a need to evaluated such chemicals for possible genotoxic, mutagenic and carcinogenic effects. The majority of carcinogenic chemicals are capable of interacting with genetic material and there is a correlation between mutagenicity and carcinogenicity, with sufficient information available to suggest that cancer can be induced by mutational events (Barrett, 1993). However, since genotoxic agents produce alterations in DNA they can be detected by genetic assays and it is important that new chemical agents and biological materials are subjected to genotoxicity tests before being used by the general public (Ames et al., 1973; Croce, 2001; Miyazaki et al., 2002).

A variety of in vitro mammalian cell gene mutation tests have been widely used for investigating the genotoxic

Send correspondence to M.S. Mantovani. Departamento de Biologia Geral, Universidade Estadual de Londrina, Campus Universitário, Caixa Postal 6001, 86051-990 Londrina, PR, Brazil. E-mail: biomsm@uel.br. and antigenotoxic effects of chemical agents, including the cytokinesis-block micronucleus (CBMN) clastogenic/ aneugenic assay to detect macrolesions and the hypoxanthine-guanine phosphoribosyl transferase locus (HGPRT) assay for gene mutation at the hgprt locus, both using Chinese hamster ovary cells clone K1 (CHO-K1). In the CBMN micronucleus test cytochalasin-B blocks cytokinesis but not nuclear division, resulting in the accumulation of binucleated cells in the culture and the formation of micronuclei due to the loss of chromatin as a result of structural chromosome damage (fragmentation) or a defect in the mitotic apparatus (Phelps et al., 2002; Fenech et al., 2003). The HGPRT assay is based on the fact that HGPRT is a non-essential enzyme for in vitro cell growth because purine nucleotides can be formed by de novo synthesis. In the test, hgprt locus mutants, produced by the action of the mutagen under test, lose the capacity to metabolize purine analogues such as 6-thioguanine (TG) which is thus lethal only to wild-type cells, the mutant cells being easily identified using an agar medium containing TG (Li et al., 1987; Albertini, 2001). 
The basidiomycete fungus Agaricus blazei Murrill (sensu Heinemann), also known as Agaricus brasiliensis (Wasser et al., 2002) or Agaricus subrufescens Peck (Kerrigan, 2005), has been reported to have antimutagenic and chemoprotective effects on DNA. These effects have been identified by our group mainly using aqueous extracts and tests for the induction of macrolesions in DNA, such as chromosomal aberrations (Bellini et al., 2003; Bellini et al., 2006) and micronuclei formation (Menoli et al., 2001; Oliveira et al., 2002). However, the chemoprotective effect in A. blazei aqueous extracts has not always been demonstrated and our group has shown that the antimutagenicity effects of water extracts of $A$. blazei can vary because while a V79 Chinese hamster lung cell micronucleus test showed an antigenotoxic effect of $A$. blaze $i$ aqueous extracts against the mutagen methanesulfonate (MMS) a comet test using the same cells did not (Guterrez et al., 2004). A subsequent study by us (Guterrez et al., 2005) using a V79 cell micronucleus test indicated that 3:1 chloroform/methanol extracts of $A$. blazei also had a protective effect against MMS. In both these studies, the $A$. blazei extract did not show any significant mutagenic effects.

Although A. blazei has been used by the general population to treat several diseases, including cancer (Kawagishi et al., 1989; Takusaburo and Yoshiaki, 1998; Yoshimura et al., 2005), its chemical composition has still not been completely elucidated. Various $A$. blazei extracts obtained using different solvents have been evaluated and the protective potential of compounds present in these extracts has been the subject of much published research, some by our group (Delmanto et al., 2001; Menoli et al., 2001; Luiz et al., 2003a; Machado et al., 2005; Bellini et al., 2006) and some by other researchers (Sorimachi et al., 2001; Kasai et al., 2004).

Although A. blazei methanolic extracts are generally not used by the general public there is still a need to assess their safety, not only because of their possible future us but also to shed light on the mechanism of action of A. blazei in regard to any protective functions its aqueous or organic extracts may have. In the study described in this paper we examined the mutagenic and protective capacities of fractions of $A$. blazei methanolic extracts using CHO-K1 and the CBMN and HGPRT assays.

\section{Material and Methods}

\section{Chinese hamster cell culture conditions}

The CBMN and HGPRT assays were performed using CHO-K1 cells provided by the Mutagenesis Laboratory of the Faculdade de Medicina de Ribeirão Preto, Universidade de São Paulo (USP), Ribeirão Preto-SP, Brazil. Cells were grown as monolayers in disposable culture flasks with a surface area of $25 \mathrm{~cm}^{2}$ using DMEM-F12 medium (Gibco BRL) supplemented with $10 \%(\mathrm{v} / \mathrm{v})$ fetal bovine serum (Gibco BRL) and $0.1 \%(\mathrm{v} / \mathrm{v})$ antibiotic/ antifungal solution (containing 10,000 units of penicillin, $10,000 \mu \mathrm{g}$ of streptomycin and $25 \mu \mathrm{g}$ of amphotericin $\mathrm{B} \mathrm{mL}{ }^{-1}$ ). The flasks were inoculated with cells and placed in a biological oxygen demand (BOD) incubator at $37^{\circ} \mathrm{C}$ and the cells grown for two complete $12 \mathrm{~h}$ cell cycles $(24$ h) before being used according to the protocol of each test.

\section{Preparation of $A$. blazei extracts}

Lineage 99/26 of Agaricus blazei Murrill (sensu Heinemann) was provided by staff at the Department of Crop Production, Faculdade de Ciências Agrárias, UNESP, Botucatu, Sao Paulo State, Brazil. Five A. blazei methanolic extract (ME) fractions were obtained from the Department of Chemistry, Universidade Federal de São Carlos (UFSCar), São Carlos-SP, Brazil. Extraction was as follows, $869.90 \mathrm{~g}$ of dry and ground $A$. blazei fruiting bodies was sequentially extracted with 50:50 dichloromethane/ hexane, pure dichloromethane, 50:50 dichloromethane/ methanol, absolute methanol and, finally, 50:50 methanol/water. The hydroalcoholic extract obtained was partitioned with dichloromethane and the organic phase concentrated and then partitioned with methanol/hexane to produce hexane and methanol extracts. The $11.98 \mathrm{~g}$ of methanolic extract was further purified using rapid chromatography on plain 0.063-0.200 mm silica (Kieselgel, Merck) using a sequential elution gradient of pure hexane (ME1), 90:10 hexane/dichloromethane (ME2), 60:4 hexane/dichloromethane (ME3), 40:60 hexane/dichloromethane (ME4), pure dichloromethane (ME5), 90:10 dichloromethane/methanol (ME6), 50:50 dichloromethane/methanol (ME7) and absolute methanol (ME8). Of the eight fractions, three (ME4, ME5, and ME6) were insufficient for testing so only five were used in this study (ME1, ME2, ME3, ME7 and ME8).

The fractions were provided in paste form and contained no residual methanol and were then dissolved in dimethyl sulfoxide (DMSO: Mallinckrodt Company, France) and diluted in phosphate buffered saline (PBS, containing $0.2 \mathrm{~g}$ of KCl, $0.2 \mathrm{~g}$ of $\mathrm{KH}_{2} \mathrm{PO}_{4}, 8 \mathrm{~g} \mathrm{NaCl}$ and $1.15 \mathrm{~g}$ of $\mathrm{Na}_{2} \mathrm{HPO}_{4} \mathrm{~L}^{-1}, \mathrm{pH}$ 7.4) to give a final concentration of $5 \mathrm{mg} \mathrm{mL}^{-1}$ in respect to the dry fraction. The diluted fractions were separated into batches and stored frozen at $-20{ }^{\circ} \mathrm{C}$ until use. The final concentration in the cell culture media was $100 \mu \mathrm{g} \mathrm{mL}^{-1}$ in culture.

\section{Positive control DNA damage-inducing agent}

The alkylating agent ethyl methanesulfonate (EMS: Acros Organics, USA) was used as a positive control to induce DNA damage. The EMS was always freshlyprepared by dissolving sufficient of this compound in $1 \mathrm{~mL}$ of PBS, pH 7.4, such that for both of the assays described below the final EMS concentration in the positive EMS control and the methanolic extract plus EMS cultures was $620 \mu \mathrm{g} \mathrm{mL}^{-1}$. 


\section{Cytokinesis-block micronucleus (CBMN) assay}

In the CBMN assay, CHO-K1 were grown for $24 \mathrm{~h}$, as described above, and then pretreated by adding one of the following to separate cultures: (A) $1 \mathrm{~mL}$ PBS, $\mathrm{pH} 7.4$, (negative control); (B) $1 \mathrm{~mL}$ of PBS, pH 7.4, containing sufficient EMS to produce a final EMS concentration of $620 \mu \mathrm{g} \mathrm{mL}^{-1}$ in the culture media (positive control); (C) mutagenicity assay, A. blazei fractions ME1, ME2, ME3, ME7 and ME8 added at a final concentration of $100 \mu \mathrm{g} \mathrm{mL}$ (mutagenicity assay); or (D) ME1 to ME8 plus the same concentration of EMS (ME1 $1_{\mathrm{ems}}, \mathrm{ME} 2_{\mathrm{ems}}, \mathrm{ME} 3_{\mathrm{ems}}, \mathrm{ME} 7_{\mathrm{ems}}$ and $M E 8_{\text {ems }}$ ) as in the positive control (mutagenicity assay). During treatment the cells were incubated for $3 \mathrm{~h}$ in serum-free culture medium before replacing the old medium with fresh medium supplemented with fetal bovine serum and $3 \mu \mathrm{g} \mathrm{mL}^{-1}$ of cytochalasin-B (Cyt-B: Acros Organics, USA) and the cells incubated for a further $18 \mathrm{~h}$ to block cytokinesis and produce binucleated cells. Cells were harvested by treatment with $0.025 \%(\mathrm{v} / \mathrm{v})$ trypsin at $25^{\circ} \mathrm{C}$, rapidly made hypotonic with $1 \%(\mathrm{w} / \mathrm{v})$ sodium citrate, fixed with 3:1 (v/v) methanol/acetic acid and stained for $5 \mathrm{~min}$ with $5 \%(\mathrm{v} / \mathrm{v})$ Giemsa in phosphate buffer $(0.06 \mathrm{M}$ $\mathrm{Na}_{2} \mathrm{HPO}_{4}$ and $0.039 \mathrm{M} \mathrm{KH}_{2} \mathrm{PO}_{4}, \mathrm{pH}$ 7.0). Three separate experiments $(\mathrm{n}=3)$ were carried out for each pretreatment (A, B, C and D, above) and 2000 binucleated cell were examined for pretreatment in each experiment, making a total of 6000 binucleated cells per treatment (Fenech, 2000; Garriot et al., 2002; Phelps et al., 2002). The methanol extracts without EMS constituted the mutagenicity test group while the methanol extracts with EMS formed the antimutagenicity test group. The results were analyzed using the Tukey-Kramer test at $\alpha=0.05$.

\section{Hypoxanthine-guanine phosphoribosyl transferase locus (HGPRT) assay}

The HGPRT assay was performed according to Li et al. (1987) using the same pretreatment culture conditions and treatments (A to D) as described for the CBMN assay. Treatment was again for $3 \mathrm{~h}$ using serum-free culture medium, after which the cells were treated with $0.025 \%(\mathrm{w} / \mathrm{v})$ trypsin, mixed and distributed into new flasks to determine cytotoxicity and expression, if any, of the mutant genotype. Cytotoxicity was determined in three replicate flasks each containing 125 to 150 cells, which were examined after seven days for the capacity to form colonies. Flasks used for expression of the mutant phenotype were seeded with $2 \times 10^{6}$ cells, incubated for $48 \mathrm{~h}$ and the cells transferred to new flasks, this process being repeated every $48 \mathrm{~h}$ for eight days. After eight days the phenotypic expression of the mutation frequency was determined by adding a known number of cells to medium with and without $10 \mu \mathrm{g} \mathrm{mL}^{-1}$ of the purine analogue 6-thioguanine (TG). For each treatment there were three replicate flasks each containing 125-150 cells growing in medium without TG and 5 replicate flasks containing $10^{5}$ cells each growing in medium with TG. Cultures were then incubated again for 9-10 days. The resultant colonies were fixed in methanol, stained with $10 \%$ Giemsa $(\mathrm{v} / \mathrm{v})$, and counted. Three separate experiments $(\mathrm{n}=3)$ were carried out for each treatment. Cytotoxicity was expressed as cloning efficiency based on the number of colonies. Mutation frequency was determined phenotypically as the number of mutant colonies unable to grow without TG, calculated from the difference in the number of colonies growing on media with and without TG. The results were analyzed using the Tukey-Kramer test at $\alpha=0.05$.

\section{Results and Discussion}

In the CBMN assay the positive EMS control was, as expected, significantly different (Tukey-Kramer test, $\mathrm{p}<0.05$ ) to the PBS negative control for both the mutagenicity and antimutagenicity tests. However, neither the methanolic extract fractions alone or the fractions plus EMS $\left(\mathrm{ME}_{\mathrm{EMS}}\right)$ showed any significant induction of micronuclei compared to the negative control in either the mutagenicity or antimutagenicity tests, indicating that the fractions showed no significant mutagenicity or antimutagenicity effects (Table 1).

The mutagenicity test results for the HGPRT cytotoxicity assay suggests that all the fractions studied may be cytotoxic, as indicated by the fact that the mean number of colonies formed was significantly lower than for the PBS negative control but not significantly different to the EMS positive control (Table 1). Some fractions even showed a lower, but not significantly lower, mean number of colonies than the EMS positive control, with absolute and relative cloning efficiencies of below 50\% (Table 1). Furthermore, significantly more (Tukey-Kramer test, $\mathrm{p}<0.05$ ) cells treated with the fractions grew on the phenotype selection medium in relation to negative control cells treated with PBS only (Table 1). In addition, the mutation frequency $\left(f_{\mathrm{m}}\right)$ for the cells treated with the fractions only were very high (Table 1), as much as 0.7701 for ME3, suggesting mutagenesis at the HGPRT locus.

In the antimutagenicity test HGPRT cytotoxicity assay the mean number of colonies for the EMS positive control was, as expected, significantly lower (Tukey test, $\mathrm{p}<0.05$ ) than that for the PBS negative control (Table 1). However, although the mean number of colonies for the EMS positive control was a little lower than each of the means for the fractions plus EMS this difference was not significant (Table 1). Furthermore, the means for the fractions were lower, although not significantly lower, than that for the PBS negative control (Table 1). This indicates only a slight, or no, protective function for the extracts regarding EMS cytotoxicity. In the phenotypic selection test, none of the fractions plus EMS demonstrated a significant difference (Tukey-Kramer test, $p<0.05$ ) in the number of mutant colonies recovered as compared to the EMS positive con- 
Table 1 - Cytokinesis-block micronucleus (CBMN) assay and hypoxanthine-guanine phosphoribosyl transferase locus (HGPRT) assay results for Chinese hamster K1 cells treated with $100 \mu \mathrm{g} \mathrm{mL}^{-1}$ Agaricus blazei methanolic extract fractions (ME1 to ME8) without the addition of the mutagen ethyl methanesulfonate (EMS) in a mutagenicity test and with the addition of $620 \mu \mathrm{g} \mathrm{mL}^{-1} \mathrm{EMS}$ (ME1 $1_{\mathrm{EMS}}$ to ME $8_{\mathrm{EMS}}$ ) in an antimutagenicity test. The positive control was $620 \mu \mathrm{g} \mathrm{mL}^{-1}$ EMS and the negative control was phosphate buffered saline (PBS). The micronuclei frequency is shown as the mean \pm standard deviation. Percentage absolute cloning efficiency $\left(\% \mathrm{CE}_{\mathrm{A}}\right)$ and relative cloning efficiency $\left(\% \mathrm{CE}_{\mathrm{R}}\right)$ was based on the mean number of colonies or mutant colonies. The mutation frequency $\left(f_{\mathrm{m}}\right)$ was calculated from the number of mutant colonies unable to grow without the purine analogue 6-thioguanine.

\begin{tabular}{|c|c|c|c|c|c|c|c|}
\hline \multirow[b]{3}{*}{ Treatment group } & \multirow{3}{*}{$\begin{array}{c}\text { CBMN } \\
\text { assay } \\
\text { micronuclei } \\
\text { frequency }\end{array}$} & \multicolumn{6}{|c|}{ HGPRT assay } \\
\hline & & \multicolumn{3}{|c|}{ Cytotoxicity } & \multicolumn{3}{|c|}{ Phenotypic selection } \\
\hline & & Colonies & $\% \mathrm{CE}_{\mathrm{A}}$ & $\% \mathrm{CE}_{\mathrm{R}}$ & Mutant colonies & $\% \mathrm{CE}_{\mathrm{A}}$ & $f_{\mathrm{m}}\left(\mathrm{x} 10^{-5}\right)$ \\
\hline \multicolumn{8}{|l|}{ Mutagenicity test } \\
\hline ME1 & $11 \pm 5.2$ & $30.5^{* \dagger}$ & 24.40 & 41.61 & $29.0 *^{\dagger}$ & 54.80 & $0.5292 *{ }^{\dagger}$ \\
\hline ME2 & $13.7 \pm 5.5$ & $13.7^{* \dagger}$ & 10.96 & 18.69 & $26.0^{* \dagger}$ & 49.84 & $0.5217^{* \dagger}$ \\
\hline ME3 & $10.8 \pm 3$ & $37.0^{*^{\dagger}}$ & 29.60 & 50.48 & $34.5 *^{\dagger}$ & 44.80 & $0.7701 *^{\dagger}$ \\
\hline ME7 & $13.5 \pm 8$ & $30.7^{* \dagger}$ & 24.56 & 41.88 & $17.4^{* \dagger}$ & 52.80 & $0.3295^{*}$ \\
\hline ME8 & $16.7 \pm 7.3$ & $24.7 *^{\dagger}$ & 19.76 & 33.70 & $16.5^{*^{\dagger}}$ & 50.40 & $0.3274 * \dagger$ \\
\hline Positive control & $27.5 \pm 15.9 *$ & $32.3 *$ & 26.16 & 44.61 & $17.2^{*}$ & 52.88 & $0.3252^{*}$ \\
\hline Negative control & $6.7 \pm 6$ & 73.3 & 58.64 & - & 0.4 & 95.04 & 0.0042 \\
\hline \multicolumn{8}{|c|}{ Antimutagenicity test } \\
\hline$M E 1_{\mathrm{SEM}}$ & $25.3 \pm 9.0$ & $100.0^{\dagger}$ & 80.00 & 68.87 & $35.2 *^{\dagger}$ & 60.28 & $0.5839 *^{\dagger}$ \\
\hline $\mathrm{ME}_{\mathrm{SEM}}$ & $24.7 \pm 4.7$ & $108.2^{\dagger}$ & 86.56 & 74.52 & $42.5^{* \dagger}$ & 83.32 & $0.5101^{* \dagger}$ \\
\hline $\mathrm{ME}_{\mathrm{SEM}}$ & $32 \pm 6.5$ & $111.7^{\dagger}$ & 89.36 & 76.93 & $42.1^{* \dagger}$ & 88.24 & $0.4771^{* \dagger}$ \\
\hline $\mathrm{ME}_{\mathrm{SEM}}$ & $49.7 \pm 10.7$ & $119.3^{\dagger}$ & 95.36 & 82.09 & $34.0^{* \dagger}$ & 97.08 & $0.3502^{* \dagger}$ \\
\hline $\mathrm{ME}_{\mathrm{SEM}}$ & $31 \pm 4.5$ & $108.2^{\dagger}$ & 86.56 & 74.52 & $26.1^{* \dagger}$ & 75.60 & $0.3452^{* \dagger}$ \\
\hline Positive control & $27.5 \pm 15.9^{*}$ & $75.5^{*}$ & 60.40 & 52.00 & $32.9^{*}$ & 56.00 & $0.5875^{*}$ \\
\hline Negative control & $6.7 \pm 6$ & 145.2 & 116.16 & - & 3.4 & 101.08 & 0.0336 \\
\hline
\end{tabular}

*Statistically significant difference within the same column and treatment group as compared to the negative control for that treatment group (TukeyKramer test $\mathrm{p}=0.001<\mathrm{p}<0.05)$.

${ }^{\dagger}$ No statistically significant difference within the same column and treatment group as compared to the positive control for that treatment group (Tukey-Kramer test $\mathrm{p}=0.001<\mathrm{p}<0.05$ ).

trol but all the fractions plus EMS, and the EMS positive control, showed significantly more (Tukey-Kramer test, $\mathrm{p}<0.05)$ mutant colonies when compared to the PBS negative control (Table 1). The lack of chemoprotective effect by the fractions was also evident from the high phenotype selection absolute cloning efficiency in selective medium and the high mutation frequencies, all being statistically equal to the EMS positive control but different to the negative control.

Many fungi are capable of producing secondary metabolites, some of which are pigments, antimicrobials or toxins for plants and animals. Fungal toxins can disrupt cellular energy production, inhibit glucose transport, block protein synthesis and cause the formation of DNA adducts, the latter being responsible for the carcinogenic and mutagenic properties of some fungi (Mizuno, 1995).

The basidiomycete A. blazei has been extensively consumed as a food and therapeutic agent and aqueous extracts of this fungi have been substantially investigated for their antimutagenic, antigenotoxic, anticarcinogenic and anticlastogenic potentials in various test systems by our group (Delmanto et al., 2001; Menoli et al., 2001; Barbisan et al., 2002; Bellini et al., 2003; Machado et al., 2005; Bellini et al., 2006) and by other researchers (Osaki et al., 1994).

We examined A. blazei methanolic extract fractions only and found that in the CBMN assay none of the fractions showed any antimutagenic effect. However, the HGPRT cytotoxicity assay indicated that all the fractions may have some toxic effect. In addition, no antimutagenic effect was found after selection of the HGPRT mutant phenotype, supporting our results with the CBMN assay.

Studies by our group have reported chemoprotective activity for $A$. blazei extracts, but it is evident that the protective effect depends on type of extract and which components (aqueous or organic) are present in its composition (Luiz et al., 2003a; Luiz et al., 2003b; Bellini et al., 2006). Our group has also reported that that $A$. blazeiaqueous extracts from different geographic locations varied in antigenotoxic activity, some being more efficient while others had no protective effect (Guterrez et al., 2004). Moreover, the chemoprotection provided by such extracts is variable depending on the type of damage caused by the damage-inducing agent, with a specific extract being protective 
against one agent but not necessarily against others. Members of our group have also shown that aqueous extracts can have a protective effect in mice against the in vivo clastogenicity induced by cyclophosphamide (Delmanto et al., 2001) and we have also reported an in vitro antimutagenic effect against methyl methanesulfonate (Menoli et al., 2001; Bellini et al., 2003). To date, studies of $A$. blazei have shown no mutagenic effects for $A$. blazei extracts, for example, we made $A$. blazeiaqueous infusions at different temperatures and tested them using the CBMN and comet assays but found no mutagenic effects. (Oliveira et al., 2002).

In our experiments, because the methanol was used as solvent only, and was totally evaporated from the $A$. blaze $i$ extracts, it is unlikely that it could have damaged the DNA. However, since we conducted no tests for methanol or methylation, further studies are needed to confirm the absence of these factors. The HGPRT assay detects more subtle DNA changes (point mutations) than CBMN assay ( $\mathrm{Li}$ et al., 1987), which may explain why the former, but not the latter, detected mutagenic effects.

Only a few studies have been accomplished with $A$. blazei organic extracts. These include the study in our laboratory by Guterrez et al. (2004), who evaluated A. blazei organic extracts using the CBMN and comet assays but found no significant genotoxic effects. We have also used CHO$\mathrm{K} 1$ cells and a chromosomal aberration test to assess a $3: 1$ chloroform/methanol A. blazei extract and found that when the extract was present at a concentration of $0.83 \%$ there was a significant decrease in mitotic index (Luiz et al., 2003a). We have tested sub-fractions of an hexanic extract of $A$. blazei and found differences in genotoxicity and cytotoxicity between the extracts (Machado et al., 2005). We also tested different $A$. blazeiorganic extracts (hexanic, methanolic and $n$-butanolic) using an in vitro chromosome aberration test and found anticlastogenicity activity but when a metabolic cell lineage and the CBMN assay was used we observed that the $n$-butanolic extract produced genotoxic effects (Bellini et al., 2006). Taken together, these results suggest that $A$. blazeiorganic extracts can contain substances with cytotoxic, mutagenic and/or antimutagenic effects. However, manifestation of these effects depends on the cell system, type of assay and protocols used, all of which could be involved in effects attributed to A. blazeiextracts. Our findings regarding the mutagenic effects of methanolic $A$. blazeiextracts are supported by similar findings in respect of methanolic extracts of African plants, which have also demonstrated mutagenicity (Elgorashi et al., 2003; Reid et al., 2006).

Our results suggest that all the fractions possess cytotoxic and mutagenic potential, but no clastogenic and/or aneugenic effects. Chemical evaluation of the fractions has not yet been made, which means that a more detailed discussion on the biological activity of the fractions cannot be made. The apparent low effectiveness of $A$. blazei metha- nolic extracts in protecting DNA and the possible adverse effects of these methanolic extracts reported in the present paper contrast with previous results relating to $A$. blazei aqueous extracts published by us and other workers suggest that it is better to use $A$. blazei as an unprocessed simple aqueous infusion. It is possible that the protective effect of A. blazeiaqueous extracts may be due to a mixture or complex of compounds and not just a single component, which would account for loss of activity when more purified extracts are studied.

Summarizing, our results suggest that the A. blazei methanolic fractions tested do not provide chemoprotection, and that all fractions are potentially mutagenic as determined by the HGPRT assay. Furthermore, it is evident that more tests are necessary for the investigation of the biological effects of both methanolic and aqueous A. blazei extracts and their interactions with cell metabolism before recommending their large-scale use by the general public, something which is already occurring in various countries. These findings indicate that $A$. blazei methanolic extract should not be used due to their genotoxicity and care should be taken in the use of $A$. blazei by the general population until further biochemical characterization of this fungi is completed.

\section{Acknowledgments}

This study was supported by the Universidade Estadual de Londrina (UEL) and the Brazilian agencies Coordenação de Aperfeiçoamento de Pessoal de Nível Superior (CAPES), Fundação de Amparo à Pesquisa do Estado de São Paulo (FAPESP), Conselho Nacional de Desenvolvimento Científico e Tecnológico $(\mathrm{CNPq})$ and Fundação Araucária.

\section{References}

Albertini RJ (2001) HPRT mutations in humans: Biomarkers for mechanistic studies. Mutat Res 489:1-16.

Ames BN, Durston WE, Yamasaki E and Lee FD (1973) Carcinogens are mutagens: A simple test system combining liver homogenates for activation and bacteria for detection. Proc Nat Acad Sci USA 70:2281-2285.

Barbisan LF, Miyamoto M, Scolastici C, Salvadori DMF, Ribeiro LR, Eira AF and Camargo JLV (2002) Influence of aqueous extract of Agaricus blazei on rat liver toxicity induced by different doses of diethylnitrosamine. J Ethnopharmacol $83: 25-32$.

Barrett JC (1993) Mechanisms of multstep carcinogenesis and carcinogen risk assessment. Environ Health Perspect 100:9-12.

Bellini MF, Angeli JPF, Matuo R, Terezan AP, Ribeiro LR and Mantovani MS (2006) Antigenotoxicity of Agaricus blazei mushroom organic and aqueous extracts in chromosomal aberration and cytokinesis block micronucleus assays in CHO-K1 and HTC cells. Toxicol In Vitro 20:355-360.

Bellini MF, Giacomini NL, Eira AF, Ribeiro LR and Mantovani MS (2003) Anticlastogenic effect of aqueous extracts of 
Agaricus blazei on $\mathrm{CHO}-\mathrm{K} 1$ cells, studying different developmental phases of the mushroom. Toxicol In Vitro 17:465-469.

Croce CM (2001) How can we prevent cancer? Proc Nat Acad Sci USA 98:10986-10988.

Delmanto RD, De Lima PLA, Suguia MM, Salvadori DMF, Da Eira AF, Speit GE and Ribeiro LR (2001) Antimutagenic effect of Agaricus blazei Murrill mushroom on the genotoxicity induced by cyclophosphamide. Mutat Res 496:15-21.

Elgorashi EE, Taylor JLS, Maes A, van Staden J, De Kimpe N and Verschaeve L (2003) Screening of medicinal plants used in South African traditional medicine for genotoxic effects. Toxicol Letters 143:195-207.

Fenech M (2000) The in vitro micronucleus technique. Mutat Res 455:81-95.

Fenech M, Chang WP, Kirsch-Volders M, Holland N, Bonassi S and Zeiger E (2003) HUMN project: Detailed description of the scoring criteria for the cytokinesis-block micronucleus assay using isolated human lymphocyte cultures. Mutat Res 534:65-75.

Garriot MI, Phelps JB and Hoffman WP (2002) A protocol for the in vitro micronucleus test I. Contributions to the development of a protocol suitable for regulatory submissions from an examination of 16 chemicals with different mechanisms of action and different levels of activity. Mutat Res 517:123-134.

Guterres ZR, Mantovani MS, Ferreira da Eira A, Ribeiro LR and Jordão BQ (2005) Genotoxic and antigenotoxic effects of organic extracts of mushroom Agaricus blazei Murrill on V79 cells. Genet Mol Biol 28:458-463.

Guterrez ZR, Mantovani MS, Eira AF, Ribeiro LR and Jordão BQ (2004) Variation of the antimutagenicity effects of water extracts of Agaricus blazei Murrill in vitro. Toxicol In Vitro 18:301-309.

Kasai H, He LM, Kawamura M, Yang PT, Deng XW, Munkanta M, Yamashita A, Terunuma H, Hirama M, Horiuchi I et al. (2004) IL-12 Production induced by Agaricus blazei fraction $\mathrm{H}(\mathrm{ABH})$ involves Toll-like receptor (TLR). Evidence C A Medicine 1:259-267.

Kawagishi H, Ryuichi RI, Kanao T, Keishiro TM, Hitoshi S, Hagiwara IT and Nakamura TO (1989) Fractionation and antitumor activity of the water-insoluble residue of Agaricus blazei fruiting bodies. Carbohydr Res 186:267-273.

Kerrigan RW (2005) Agaricus subrufescens, a cultivated edible and medicinal mushroom, and its synonyms. Mycologia 97:12-24.

Li AP, Carver JH, Choy WN, Hsie AW, Gupta RS, Loveday KS, O'Neill JP, Riddle JC, Stankowski Jr LF and Yang LL (1987) A guide for the performance of the Chinese hamster ovary cell/hypoxanthine-guanine phosphoribosyl transferase gene mutation assay. Mutat Res 189:135-141.

Luiz RC, Jordão BQ, Eira AF, Ribeiro LR and Mantovani MS (2003a) Mechanism of anticlastogenicity of Agaricus blazei Murrill mushroom organic extracts in wild type $\mathrm{CHO}(\mathrm{k} 1)$ and repair deficient (xrs5) cells by chromosomes aberration and sister chromatid exchanges assays. Mutat Res 528:7579.

Luiz RC, Jordão BQ, Eira AF, Ribeiro LR and Mantovani MS (2003b) Non-mutagenic or genotoxic effects of medicinal aqueous extracts from the Agaricus blazei mushroom in V79 cells. Cytologia 68:1-6.

Machado MP, Rodrigues Filho E, Terezan AP, Ribeiro LR and Mantovani MS (2005) Cytotoxicity, genotoxicity and antimutagenicity of hexane extracts of Agaricus blazei determined in vitro by the comet assay and CHO/HGPRT gene mutation assay. Toxicol In Vitro 19:533-539.

Menoli RCN, Mantovani MS, Ribeiro LR, Gunter S and Jordão $\mathrm{BQ}$ (2001) Antimutagenic effects of the mushroom Agaricus blazei Murrill extracts on V79 cells. Mutat Res 496:5-13.

Miyazaki M, Ohno S, Futatsugi M, Saeki H, Ohga T and Watanabe M (2002) The relation of alcohol consumption and cigarette smoking to multiple occurrence of esophageal dysplasia and squamous cell carcinoma. Surgery 131:7-13.

Mizuno T (1995) Bioactive biomolecules of mushrooms - Food, function and medicinal effect of mushroom fungi. Food Rev Int 11:7-21.

Oliveira JM, Jordão BQ, Ribeiro LR, Eira AF and Mantovani MS (2002) Anti-genotoxic effect of aqueous extracts of sun mushroom (Agaricus blazei Murill lineage 99/26) in mammalian cells in vitro. Food Chem Toxicol 40:15-20.

Osaki Y, Kato T, Yamamoto K, Okuto J and Miyazaki T (1994) Antimutagenic and bacterial substances in the fruit body of a basidiomycete Agaricus blazei. Yakugaku-Zasshi 114:342350.

Phelps JB, Garriot ML and Hoffman W (2002) A protocol for the in vitro micronucleus test II. Contributions to the validation of a protocol suitable for regulatory submissions from an examination of 10 chemicals with different mechanisms of action and different levels of activity. Mutat Res 521:103-112.

Reid KA, Maes J, Maes A, van Staden J, De Kimpe N, Mulholland DA and Verschaeve L (2006) Evaluation of the mutagenic and antimutagenic effects of South African plants. J Ethnopharmacol 106:44-50.

Sorimachi K, Ikehara Y, Maezato G, Okubo A, Yamazaki S, Akimoto K and Niwa A (2001) Inhibition by Agaricus blazei Murill fractions of cytopathic effect induced by western equine encephalitis (WEE) virus on VERO cells in vitro. Bios Biotechnol Biochem 65:1645-1647.

Takusaburo E and Yoshiaki F (1998) Antitumor effect of peptide-glucan preparation extracted from Agaricus blazei in a double-grafted tumor system in mice. Bioth Dordr 4:259265.

Wasser SP, Didukh MY, Amazonas MALA, Nevo E, Stamets P and Eira AF (2002) Is a widely cultivated culinary-medicinal royal sun Agaricus (the Himematsutake mushroom) indeed Agaricus blazei Murrill? Int J Med Mushroom 4:267290.

Yoshimura K, Ueda N, Ichioka K, Matsui Y, Terai A and Arai Y (2005) Use of complementary and alternative medicine by patients with urologic cancer: A prospective study at a single Japanese institution. Suppl C Cancer 13:685-690.

Associate Editor: Carlos F.M. Menck 